\title{
The Influence of Post in Endodontically Treated Molar Abutment on Fixed Dentures Success Rate
}

\author{
Pralita Kusumawardhini ${ }^{1}$, Alysia Henrietta ${ }^{1}$, Saraventi ${ }^{2}$ \\ ${ }^{1}$ Undergraduate Program, Faculty of Dentistry, Universitas Indonesia, Jakarta 10430, Indonesia \\ ${ }^{2}$ Department of Prosthodontics, Faculty of Dentistry, Universitas Indonesia, Jakarta 10430, \\ Indonesia \\ Corresponding e-mail to: midorino_alit@yahoo.com
}

\begin{abstract}
Several studies had proven that endodontically treated tooth can still serve as fixed denture abutment. Many dentists believe that the tooth need reinforcement provided by post before the definite restoration is placed. However, others suggest not to use post when posterior teeth especially molars, still have significant amount of tooth structure. Therefore, when endodontically treated molar is considered to be used as fixed denture abutment, clinicians must have proper knowledge about the impact of post placement. This literature will describe considerations regarding post placement in endodontically treated molar abutment in fixed partial dentures and their influence to the success rate. Previous studies implied the need of proper measurement of the amount of remaining tooth structure, the type of intracoronal reinforcement of the abutment, and the functional loads to ensure the success of fixed denture treatment. When planning definitive restorations for endodontically treated abutment teeth, some even suggest to use post and core to fulfill the need of reinforcement. On the contrary, others find that when a post is use in endodontically treated abutment teeth, the failure of custom made-tapered cast post and core is relatively high, whereas the use of amalgam or composite core in posterior teeth especially molars with adequate amount of tooth structure is sufficient due to post system's limited influence on the success rate. Based on literature review, for cases with adequate tooth stucture, it can be concluded that the influence of post placement in endodontically treated molar abutment to fixed partial dentures success rate is very limited.
\end{abstract}

\begin{abstract}
ABSTRAK
Pengaruh penggunaan pasak pada gigi molar penjangkaran terhadap keberhasilan perawatan gigi tiruan cekat. Beberapa studi telah membuktikan bahwa gigi yang telah dilakukan perawatan endodontik masih bisa berfungsi sebagai penjangkaran gigi tiruan tetap sebagian. Banyak dokter gigi percaya bahwa gigi tersebut memerlukan penguatan dengan pembuatan pasak sebelum restorasi. Namun, ada juga yang menyarankan untuk tidak menggunakan pasak pada gigi posterior terutama geraham, karena masih memiliki jumlah struktur gigi yang cukup signifikan. Oleh karena itu, ketika molar digunakan sebagai penjangkaran gigi tiruan sebagian tetap, dokter gigi harus memiliki pengetahuan yang tepat tentang dampak dari penempatan pasak tersebut. Studi literatur ini akan menjelaskan mengenai pertimbangan penempatan pasak pada molar paska perawatan endo sebagai penjangkaran gigi tiruan sebagian tetap dan tingkat keberhasilannya. Literatur menyatakan kebutuhan pengetahuan yang tepat mengenai pengukuran jumlah sisa struktur gigi, jenis pasak intrakoronal, dan beban fungsional untuk memastikan keberhasilan gigi tiruan sebagian tetap. Literatur juga menyatakan untuk menggunakan pasak beserta inti pasak yang tepat untuk memenuhi kebutuhan sebgai penguatan struktur gigi. Sebaliknya, ada yang mengemukakan kegagalan pasak relatif tinggi, sedangkan penggunaan amalgam atau komposit pada gigi mempunyai tingkat keberhasilan yang baik. Didasarkan pada kajian pustaka, dapat disimpulkan bahwa penggunaan gigi molar paska perawatan endodontik sebagai penjangkaran gigi tiruan sebagian tetap, mempunyai tingkat keberhasilan yang terbatas.
\end{abstract}

Keywords: abutment, endodontic, fixed denture, molar 


\section{INTRODUCTION}

Several studies had proven that endodontically treated tooth can still serve as fixed partial denture abutment. ${ }^{1-8}$ In those case, fixed partial denture also functioned as restoration of the endodontically treated tooth. Restoring endodontically treated tooth can be problematic to dental practitioners because the tooth have lost considerable amount of structure due to caries, previous restoration or endodontic treatment itself. Consequently, there is a widely held view that endodontically treated tooth need reinforcement provided by post before the definite restoration is placed. ${ }^{2}$ However, when endodontically treated molar is considered to be used as fixed denture abutment, there are factors affecting clinician to make a decision regarding the need to use post as reinforcement. ${ }^{9-12}$ Therefore, dentist must have proper knowledge about the impact of post placement. ${ }^{1}$ This literature will describe considerations concerning post placement in endodontically treated molar abutment in fixed dentures and their influence to the success rate. This would hopefully allow the stipulation of optimal treatment planning to achieve the best possible prognosis in individual patient cases.

\section{LITERATURE STUDY}

\section{Endodontically treated tooth as fixed partial den- ture abutment}

The mandibular molars, maxillary molars and mandibular anterior were the most common teeth to develop endodontic complications during preparation or after cementation of fixed denture and subsequently required endodontic treatment. The incidence has ranged from $3 \%$ to $23 \%$. Regardless, endodontically treated teeth generally have a good prognosis. $^{2,13}$ They can resume full function and can still serve as abutments for fixed partial dentures when adjacent edentulous spans are to be prosthetically restored. ${ }^{1}$ It was claimed that the success rate of endodontically treated tooth served as fixed partial denture abutments are between $89.2 \%$ to $96.2 \%$ with 1 to 25 years time range. ${ }^{20}$ This was inline with a study which studied crowns and fixed partial dentures over 25 years at a school of dentistry and found that the overall survival rates for vital and endodontically treated abutments were the same, as were the survival rates for large or small fixed partial denture. However, others suggest that nonvital, endodontically treated abutments have a higher failure rate than vital abutments and that this difference increases with time. This is related to the loss of the tooth structure associated with caries, subsequent access preparations that lead to a higher fracture rate in endodontically treated teeth compared with vital teeth, rather than changes in dentin. ${ }^{1-2,14}$ Thus, the amount of remaining dentin became the key factor that determine the strength of endodontically treated teeth. 515 metal-ceramic fixed partial dentures made by a specialist prosthodontist 1 to 15 years after insertion, with 366 of the fixed partial dentures being 5 to 15 years after insertion. ${ }^{14}$ Cumulative survival rates (where only maintenance procedures were required) were $96 \%, 87 \%$, and $85 \%$ at 5,10 , and 15 years, respectively. Cantilevered fixed partial dentures, anterior abutments, and root-filled abutments had significantly greater failure rates. Root-filled abutments had failure rates of $8 \%$ after 5 to 10 years and $21 \%$ after 10 to 15 years compared with $2 \%$ and $5 \%$, respectively, for vital abutments. Overall, the most common reason for fixed partial denture retreatment was tooth fracture $(38 \%)$, although periodontal breakdown $(27 \%)$ and caries $(11 \%)$ increased significantly with time. Importantly, non rigid connection and regular professional maintenance were associated with significantly reduced fail-ure rates. This may explain to some degree why Walton found that failure was not related to the number of units in an fixed partial denture, while other studies have found a significant difference. Napankangas et al found that long fixed partial dentures (6 or more units) had a lower survival rate after 10 years than short fixed partial dentures ( 3 to 5 units). The survival rate after 10 years in their study was $84 \%$, which is comparable to the $87 \%$. ${ }^{14}$ Overall, the literature suggests that the use endodontically treated distal abutments should be avoided in cantilevered fixed partial dentures. In other circumstances, endodontically treated tooth should be used with caution, as higher failure rates than with vital abutments can be expected. A strict protocol should be applied on the basis of mechanical and biological principles, such as selective use of non rigid connectors, conservation of dentin, provision of a ferrule, and a professional maintenance program. ${ }^{1}$

\section{The need of post in endodontically treated molar} A post is a rigid structure placed in the canal of a non -vital tooth which extends coronally to hold the core material that supports the crown. Post will stabilize endodontically treated teeth, but would increased the risk of fracture due to more dentine is removed. Other studies have shown that post does not strengthen the tooth; it only serves to improve retention of core. The primary purpose of a post is to retain a core in a tooth with extensive loss of coronal tooth structure. ${ }^{15}$ Posts have one purpose, to retain a build-up on a tooth. There is compelling evidence that they do not strengthen teeth. ${ }^{2}$ An analysis of data from multiple clinical studies noted that 3 percent of teeth with posts fractured and found no evidence that posts enhanced the survival of teeth. ${ }^{16}$ Preparation of a post space adds a certain degree of risk to a restoration procedure. Procedural accidents in the form of perforation can occur. The placement of posts also 
may increase the chances of root fracture and treatment failure, especially if an oversized post channel is prepared. Hence posts should only be used when other options are not available to retain a core. ${ }^{15}$ There are several types of post and core. The first one is cast post and core, the core is formed on the post directly on the tooth or on the cast. Prefabricated posts is another type of post which are used with a restorative build-up material, which is formed after cementation of the post. Currently the best choices are amalgam and composite resin. Amalgam has good physical and mechanical properties and works well in high-stress areas. Crown preparation must be delayed to permit the material to set. Amalgam can cause esthetic problems and can make the gingiva look dark. Moreover, they have no natural adhesive property. Composite resin is the most popular core material presently. It can be bonded to many of the current posts and to the remaining tooth structure. They possess high tensile strength and tooth can be prepared for crown immediately. It is tooth colored and can be used under translucent restorations. The trend in clinical practice is towards fiber posts and literature is generally, in favor of them. Their performance is similar to that of the metal posts and their failure mode is more favorable than with metal posts ${ }^{2}$ Where inadequate pulp chamber depth remains to retain the build-up of the core, a preformed post should be placed. On some posterior teeth such as small upper first bicuspids, cast gold post cores will be preferable to amalgam where tooth size prevents adequate bulk of build-up around the post. Where a post is needed, use a small diameter, passive round post requiring a minimum of dentin removal and use a post length that extends into the root past the crown margin by the length of the crown. Cement the post with $\mathrm{ZnPO}_{4}$ or a hybrid resin/glass ionomer cement, leaving an apical seal of $4 \mathrm{~mm}$ of gutta-percha. ${ }^{17}$ The average survival time of the post and cores was 7.3 years. The cumulative failure rate was $11.2 \%$. The most common complication was loss of retention of the post and cores. High -gold-content posts had a lower risk of failure than posts made from semi-precious alloy. The type of restoration fitted had a significant influence on the survival probability. ${ }^{8}$ However, most laboratory studies have shown that placement of a post and core does not increase the fracture resistance of endodontically treated extracted teeth when a force is applied via a mechanical testing machine..$^{13}$ A crown is indicated on all endodontically treated posterior teeth. In preparing the tooth, parallel ferrule walls are essential and should be a minimum of $2 \mathrm{~mm}$ long apico-coronally. In addition, the thickness of the remaining dentin should be no less than $1 \mathrm{~mm}$ on the buccal and lingual wall areas, and optimally interproximally as well. ${ }^{17}$ If the axial walls of the cavity remain and have thickness greater than $1 \mathrm{~mm}$ it is not necessary to insert post. ${ }^{15}$ However, a cast post and- core is indicated if a substantial amount of coronal structure is missing. ${ }^{4}$ In other condition, the axial reduction for a crown preparation (peripheral destruction) combined with an endodontic access preparation (central destruction) frequently leaves insufficient sound dentine to support a crown. In this case, a post and core probably is needed. ${ }^{3}$ On posterior teeth in which the core build-up can be retained by remaining pulp chamber anatomy there is no need or advantage to placement of a post. ${ }^{17}$ Molars must resist primarily vertical forces. In those molars that do require a post, the post should be placed in the largest, straightest canal, which is the palatal canal in the maxillary molars and a distal canal in the mandibular molars. Rarely, if ever, is more than one post required in a molar. ${ }^{22}$ Posts have had little enhancing effect on the clinical success of fixed partial denture abutments, but they have improved the clinical success of removable partial denture abutments compared with endodontically treated abutments where no posts were used. ${ }^{16}$

\section{The influence of post placement in endodontically treated molar abutment of fixed partial denture success rate}

Different methodologies and criteria for success and varying material being studied in the topic of the influence of post placement in endodontically treated teeth as fixed denture's abutment make comparison among different studies difficult. Nevertheless, this literature will try to describe various trends among studies and provide experiment based recommendations. Difference in the surviving fixed partial dentures from the successful one. ${ }^{14}$ The successful fixed partial denture defined as ones that fully intact and functional, whereas the surviving ones are fixed dentures that still functional but have degraded in repairable ways. In accordance with most literature, this review define success as fixed partial denture which survive and considerably intact and functional. ${ }^{14}$ Studies of crowns and fixed partial dentures over 25 years at a school of dentistry and found that the overall survival rates for vital and endodontically treated abutments were the same, as were the survival rates for large or small fixed partial dentures. Caries was found to be the leading cause of abutment tooth failure. Previous study which clinically and radiographically examined 103 fixed dentures with a length of at least 5 units 18 to 23 years after insertion. The fixed partial dentures had been made by specialists and general practitioners at a public clinic. It was found that out of 487 abutment teeth, $14 \%$ had been removed during the observation period. The percentage of vital abutments removed was $10 \%$, and for endodontically treated teeth it was significantly higher at $24 \%$. Very high percentages were recorded for the removal of endodontically treated teeth serving as terminal abutments withand without cantilever extension $(29 \%$ to $38 \%){ }^{1}$ Endodontically 
treated, molar teeth should receive cuspal coverage, but in most cases, do not require a post. Unless the destruction of coronal tooth structure is extensive, the pulp chamber and canals provide adequate retention for a core buildup. ${ }^{22}$ This may be one of the reason why many studies implied posts and cores have little influence on the clinical success of fixed partialdenture abutments. ${ }^{1,7}$ A study conclude that preparing a post space weakened endodontically treated teeth compared with ones in which only an access opening was made, but no post space. They also found that cemented Paraposts (Coltenel Whaledent Inc, New York, NY) did not increase the fracture resistance. Kantor and Pinesz determined that cementing a stainless steel rod into prepared post spaces of teeth that had also been prepared for complete coverage crowns increased the fracture resistance compared with teeth that were only prepared for complete crowns but had no post. ${ }^{13}$ The relatively high failure rate after post insertion found in this study is in agreement with the one reported by Stockton et al in which the success and possible failure causes after post insertion were investigated. While secondary caries is the most common failure reason, post dislodgement and the restoration type (provisional or definitive) are also considered to influence the failure rate as also shown in this study. Furthermore, root fracture, post dislodgement and coronal restoration fractures are also among the relevant failure factors of endodontically treated teeth that have been restored with a post. The results suggest that the prognosis of endodontically treated teeth could be favorably enhanced if the insertion of pre-fabricated and casted metal posts is avoided. ${ }^{9}$ Similar to other research, there is a statement that said preparation of a post space adds a certain degree of risk to a restoration procedure.

Procedural accidents in the form of perforation can occur. The placement of posts also may increase the chances of root fracture and treatment failure, especially if an oversized post channel is prepared. Hence posts should only be used when inadequate tooth structure is present. ${ }^{2}$ Another study have determined that on posterior teeth in which the core build-up can be retained by remaining pulp chamber anatomy there is no need or advantage to placement of a post. ${ }^{18-20}$ Furthermore, some suggest that molar teeth with an adequate pulp chamber do not require a post. ${ }^{7}$ Walton studied 515 teeth for 15 years and conclude that there was no statistically significant difference in the long-term survival of complete crowns on vital abutments versus post-and-core complete crowns or in the survival of 3-unit fixed partial dentures on vital abutments versus those with at least 1 endodontically treated abutment. For fixed partial dentures with more than 3 units and cantilevered fixed partial dentures, the use of a post and core abutment led to significantly more failures. ${ }^{21}$

\section{DISSCUSSION}

The review of literatures above suggest reevaluation of dental practitioner approach in using endodontically treated tooth, especially molar as abutment of fixed partial denture. Each individual case must be handled with specifically. The divergence of treating endodontically treated molar abutment of fixed partial denture reflects the lack of understanding by clinicians which can lead to decreased success rates. Success rate of fixed partial denture treatment commonly measured by the longevity of the restoration and their ability to function optimally. The success and survival rate of endodontically treated teeth depends on the careful endodontic treatment and subsequent definitive restoration. ${ }^{9,17}$ Endodontically treated molar teeth oftenly used as fixed partial denture abutments when adjacent edentulous spans are to be prosthetically restored. Although traditional paradigm condemned them as unfit abutments, nowadays, many research and literature have proved that they can resume full function and can still serve as abutments for fixed partial dentures. However, many dental practitioners still feel obligate to reinforce endodontically treated molar abutment by the means of post and core. ${ }^{1}$ This believe in not completely wrong according to Hunter el al who determined that removal of internal tooth structure during endodontic therapy is accompanied by a proportional increase in stress consequently a post is needed substantially to reinforce the tooth. However, this only applied when considerable root canal enlargement has occurred. Furthermore, they also determined that minimal root canal enlargement for a post does not substantially weaken a tooth. Bergmann et al. have similar discovery and found a significantly lower risk of failure if the post and cores were fitted with crowns or bridges. ${ }^{7,13,17}$ Nonetheless, several studies found that there was found to be no difference among failure rates of endodontically treated teeth restored with a crown or complete crown coverage such as fixed partial denture, either prepared with a post and core or a core without a post. ${ }^{17}$ Moreover, when a post is use in endodontically treated abutment teeth, especially molar, the failure of post and core is relatively high, whereas the use of amalgam or composite core in posterior teeth especially molars with adequate amount of tooth structure is sufficient due to post system's limited influence on the success rate. In accordance with Martinoff and Sorensen findings, Charles et al came to conclusion that post placement had limited influence on the success rate of fixed partial denture abutments, especially when the abutment is molar tooth with significant amount of tooth structure. ${ }^{13}$ McComb explains that endodontically treated, molar teeth should receive cuspal coverage, but in most cases, do not require a post. Unless the destruction of coronal tooth structure is extensive, the pulp chamber and canals 
provide adequate retention for a core buildup. ${ }^{22}$ This may be one of the reason why many studies implied posts and cores have little influence on the clinical success of fixed partial denture abutments. The criteria for a tooth to be considered adequate to served as abutments after endodontically treated are parallel ferrule walls height should be a minimum of $2 \mathrm{~mm}$ long apico-coronally. ${ }^{8}$ In addition, the thickness of the remaining dentin should be no less than $1 \mathrm{~mm}$ on the buccal and lingual wall areas, and optimally interproximally as well. ${ }^{11,17}$ Some authors consider the placement of a post before prosthetic rehabilitation as obligatory while others believe that post space preparation may further weaken the abutment tooth. Therefore, post placement should only be considered if retention for final fixed partial dentures or removable partial dentures is inadequate and does not have the objective of strengthening the endodontically treated tooth. One study showed that the most relevant factor for longevity of a post and core restoration is the amount of remaining dentin height after tooth preparation. However, data on the clinical outcome of abutments for fixed partial dentures in particular with posts is scarce. On the other hand, because both laboratory and clinical data fail to provide definitive support for the concept that posts strengthen endodontically treated teeth, many believe that post space preparation may further weaken the abutment tooth. Therefore, post placement should only be considered if retention for final fixed partial dentures or removable partial is inadequate and does not have the objective of strengthening the endodontically treated tooth. One study showed that the most relevant factor for longevity of a post and core restoration is the amount of remaining dentin height after tooth preparation. ${ }^{17}$

\section{CONCLUSION}

An endodontically treated tooth should have a good prognosis and be able to resume full function and serve satisfactorily as an abutment for a fixed partial denture. Proper techniques are needed to restore such a tooth. Two factors that influence the choice of technique are the type of tooth and the amount of remaining tooth structure. The latter is probably the most important indicator when determining the prognosis. Proper assessment of remaining dentin is therefore an important element in the evaluation of a tooth's prognosis regarding endodontic therapy and also any subsequent restorative procedures. It is the decision of the operating dentist whether to place a post or not. This decision is a process incorporated into the patient's comprehensive treatment plan and involves both patient and practitioner factors. Patient factors include individual needs such as cost, time and comfort, the overall condition of the dentition, the position of the tooth in the arch and the accompanying functional demands placed upon it while practitioner variables include degree of skill and knowledge. Therefore, based on literature review, we can conclude that for cases where there are still adequate tooth structure, particularly of molar tooth, the influence of post placement in endodontically treated abutment to fixed partial dentures success rate is very limited.

\section{REFERENCES}

1. Goga R, Purton DG. The use of endodontically treated teeth as abutments for crowns, fixed partial dentures, or removable partial dentures: a literature review. Quintessence Int. 2007;92:10611.

2. Vidyashree V, Nandini V, Venkatesh. Current concepts in the restoration of endodontically treated teeth. J Indian Prosthodont Soc. 2006;2:63-7.

3. Shillingburg HT, Hobo S, Whitsett LD, Jacobi R, Brackett SE. Fundamental of fixed prosthodontics, 3rd Ed. Chicago, Illinois: Quintessence Publishing Co. Inc.; 1997.

4. Rosenstiel SF, Land MF, Fujimoto J. Contemporary fixed prosthodontics. 3rd ed. St. Louis, Missouri: Mosby Inc; 2001.

5. Ingle JI, Bakland LK, Baumgartner JC. Ingle's Endodontic. 6th ed. Ontario: BC Decker; 2008.

6. Sorensen JA, Martinoff JT. Endodontically treated teeth as abutments. J Prosthet Dent. 1985;53: 631-6.

7. McComb D. Restoration of the endodontically treated tooth. Royal College of Dental Surgeon of Ontario, 2008:1-20.

8. Wegner PK, Freitag S, Kern M. Survival rate of endodontically treated teeth with posts after prosthetic restoration. J Endod. 2006;32:928-31.

9. Willershausen B, Tekyatan H, Krummenauer F, Marroquin BB. Survival rate of endodontically treated teeth in relation to conservative vs post insertion techniques- a retrospective study. J Med Res. 2005;10:204-8.

10. Derfeldt SO, Palmqvist S. A multilevel analysis of factors affecting the longevity of fixed partial dentures, retainers and abutments. J Oral Rehabil. 1998;25:242-52.

11. Eckerbom M, Magnusson T. Restoring endodontically treated teeth: a survey of current opinions among board-certified prosthodontists and general dental practitioners in Sweden. Int J Prosthodont. 2001;14:245-9.

12. De Backer H, Van Maele G, Van den Berghe L. Long-term survival of complete crowns, fixed dental prostheses, and cantilever fixed dental prostheses with posts and cores on root canaltreated teeth. Quintessence Int. 2007;20;229-34.

13. Goodame CJ, Splnik KJ. The prosthodontic 
management of endodontically treated teeth: a literature review. Part I. success and failure data, treatment concepts. J Prosthod. 1994;3:243-50.

14. Walton TR. An up to 15-year longitudinal study of 515 metal-ceramic fixed partial dentures: part 1. outcome. Int J Prosthodont. 2002;15:439-45.

15. Michael MC, Husein A, Wan Bakar WZ, Sulaiman E. Fracture resistance of endodontically treated teeth: an in vitro study. Arc of Orofacial Sci. 2010:5:36-41.

16. Baba NZ, Goodacre CJ. Key principles that enhance success when restoring endodontically treated teeth. Roots. 2010;31.

17. McLean A. Predictably restoring endodontically treated teeth. Roots. 1998;64:11.

18. Nayyar A, Walton RE, Leonard LA. An amalgam coronal-radicular dowel and core technique for endodontically treated posterior teeth. J Prosthet Dent. 1980;43:511-15.

19. Kane JJ, Burgess JO, and Summitt JB. Fracture resistance of amalgam coronal-radicular restorations. J Prosthet Dent. 1990;63:607-13.

20. Sorensen JA, Martinoff JT. Clinically significant factors in dowel design. J Prosthet Dent. 1984;52:28-35.

21. Posts and Cores on Root Canal-Treated Teeth. Int J Prosthodont. 2007;20:229-34.

22. Schwartz RS, Robbins JW. Post placement and restoration of endodontically treated teeth: A literature review. J Endond. 2004;30:5. 